medRxiv preprint doi: https://doi.org/10.1101/2021.10.12.21264858; this version posted October $29,2021$. The copyright holder for this preprint (which was not certified by peer review) is the author/funder, who has granted medRxiv a license to display the preprint in All rights reserved. No reuse allowed without permission.

\title{
Cohort Profile Update: The HUNT Study, Norway
}

Bjørn Olav Åsvold ${ }^{1,2,3}$, Arnulf Langhammer ${ }^{1,4}$, Tommy Aune Rehn ${ }^{5}$, Grete Kjelvik ${ }^{6}$, Trond Viggo Grøntvedt ${ }^{1}$, Elin Pettersen Sørgjerd ${ }^{1,3}$, Jørn Søberg Fenstad ${ }^{1}$, Oddgeir Holmen ${ }^{1}$, Maria C Stuifbergen ${ }^{1}$, Sigrid Anna Aalberg Vikjord ${ }^{1,7}$, Ben M Brumpton ${ }^{1,2,8}$, Håvard Kjesbu Skjellegrind ${ }^{1,4}$, Pernille Thingstad ${ }^{9,10}$, Erik R Sund ${ }^{1,4,11}$, Geir Selbæk ${ }^{6,12,13}$, Paul Jarle Mork ${ }^{5}$, Vegar Rangul ${ }^{1,11}$, Kristian Hveem $^{1,2,4}$, Marit Næss ${ }^{1,4}$, Steinar Krokstad ${ }^{1,4}$

${ }^{1}$ HUNT Research Centre, Department of Public Health and Nursing, Faculty of Medicine and Health Sciences, NTNU, Norwegian University of Science and Technology, NTNU, Levanger, Norway

${ }^{2}$ K.G. Jebsen Center for Genetic Epidemiology, Department of Public Health and Nursing, NTNU, Norwegian University of Science and Technology, Trondheim, Norway

${ }^{3}$ Department of Endocrinology, Clinic of Medicine, St. Olavs hospital, Trondheim University Hospital, Trondheim, Norway

${ }^{4}$ Levanger Hospital, Nord-Trøndelag Hospital Trust, Levanger, Norway

${ }^{5}$ Department of Public Health and Nursing, Faculty og Medicine and Health Sciences, Norwegian University of Science and Technology, NTNU, Trondheim, Norway

${ }^{6}$ Norwegian National Advisory Unit on Ageing and Health (Ageing and Health), Tønsberg, Norway ${ }^{7}$ Department of Medicine and Rehabilitation, Levanger Hospital, Nord-Trøndelag Hospital Trust, Levanger, Norway

${ }^{8}$ Clinic of Medicine, St. Olavs hospital, Trondheim University Hospital, Trondheim, Norway ${ }^{9}$ Department of Neuromedicine and Movement Science, Faculty of Medicine and Health Sciences, NTNU, Norwegian University of Science and Technology, Trondheim, Norway

${ }^{10}$ Department of Health and Social Services, Trondheim Municipality, Trondheim, Norway

${ }^{11}$ Faculty of Nursing and Health Sciences, Nord University, Levanger, Norway

${ }^{12}$ Department of Geriatric Medicine, Oslo University Hospital, Oslo, Norway

${ }^{13}$ Faculty of Medicine, University of Oslo, Oslo, Norway

NOTE: This preprint reports new research that has not been certified by peer review and should not be used to guide clinical practice. 
medRxiv preprint doi: https://doi.org/10.1101/2021.10.12.21264858; this version posted October 29,2021 . The copyright holder for this preprint (which was not certified by peer review) is the author/funder, who has granted medRxiv a license to display the preprint in All rights reserved. No reuse allowed without permission.

Corresponding author:

Bjørn Olav Åsvold

Department of Public Health and Nursing, NTNU, Norwegian University of Science and Technology, Postboks 8905 MTFS, NO-7491 Trondheim, Norway

Email: bjorn.o.asvold@ntnu.no

Word count: 2404

\section{Abstract:}

In the HUNT Study, all residents aged $\geq 20$ years in the Nord-Trøndelag region, Norway have been invited to repeated surveys since 1984-86. The study data may be linked to local and national health registries. The HUNT4 survey in 2017-19 included 56042 participants in Nord-Trøndelag and 107711 participants in the neighboring Sør-Trøndelag region. The HUNT4 data enable more long-term follow-up, studies of life-course health trajectories, and within-family studies. New measures include body composition analysis using bioelectrical impedance; a one-week accelerometer recording; physical and cognitive testing in older adults; measurements of hemoglobin and blood cell counts, $\mathrm{HbA1c}$ and phosphatidylethanol; and genotyping. Researchers can apply for HUNT data access from HUNT Research Centre if they have obtained project approval from the Regional Committee for Medical and Health Research Ethics, see www.ntnu.edu/hunt/data. 
medRxiv preprint doi: https://doi.org/10.1101/2021.10.12.21264858; this version posted October 29, 2021. The copyright holder for this preprint (which was not certified by peer review) is the author/funder, who has granted medRxiv a license to display the preprint in

All rights reserved. No reuse allowed without permission.

\section{The original cohort}

The Trøndelag Health Study (the HUNT Study) is a population-based cohort study of the adult population in Trøndelag County, Norway. It was previously called the Nord-Trøndelag Health Study, until the study in 2019 expanded to cover both regions of Trøndelag County, Nord-Trøndelag and Sør-Trøndelag. The study has been running in Nord-Trøndelag since 1984 and is designed to cover a broad range of health-related topics through repeated surveys with questionnaires, interviews, clinical examinations, laboratory measurements and storage of biological samples. Nord-Trøndelag is fairly representative of Norway except for the lack of large cities and immigrant populations, and the region is suitable for longitudinal studies due to low migration. The HUNT Study data can be linked to a wide range of local and national health registries by means of the unique identification number allocated to all Norwegian residents. All residents $\geq 20$ years of age in Nord-Trøndelag were invited to the HUNT1 (1984-86, 77202 participants, 89.4\% of invitees participated), ${ }^{1}$ HUNT2 (1995-97, 65228 participants, 69.5\%) ${ }^{2}$ and HUNT3 (2006-08, 50800 participants, 54.1\%) ${ }^{3}$ surveys (Figure 1). Since 1995-97, all adolescents (13-19 years of age) in Nord-Trøndelag have been invited to participate in the corresponding Young-HUNT Study. ${ }^{4}$

\section{What is the reason for the new data collection?}

In 2017-19, all adult residents of Trøndelag were invited to the HUNT4 survey. The reasons for this new survey were first, to collect follow-up and extended information on previous participants, and new information on individuals having moved into the region or reached adult age. After completion of HUNT4, about 19000 individuals have more than 30 years of follow-up spanning all four study cycles (Figure 1). The continued follow-up also allows for monitoring of secular trends in public health. Second, improved measurement methods have become available for several health and lifestyle characteristics important for public health, as described in the later sections. Third, the HUNT Study previously lacked data from a large city. In 2019, HUNT4 expanded to include a survey in Sør-Trøndelag, which includes the city of Trondheim with 202 000 inhabitants (2019). The extended 
medRxiv preprint doi: https://doi.org/10.1101/2021.10.12.21264858; this version posted October 29, 2021. The copyright holder for this preprint (which was not certified by peer review) is the author/funder, who has granted medRxiv a license to display the preprint in

All rights reserved. No reuse allowed without permission.

study population from both Nord-Trøndelag and Sør-Trøndelag is generally representative of Norway (Supplementary Table S1). A fourth reason for new data collection is the expansion of genetic and molecular epidemiology, where 70517 participants of the HUNT2 or HUNT3 surveys have been genotyped.

\section{What will be the new areas of research?}

Extended follow-up of HUNT participants and high attendance among older adults enable a stronger focus on disease incidence, progression and life-course health trajectories. New generations of HUNT participants enable more within-family and inter-generational studies. More valid studies of physical activity and anthropometry are possible due to new data including accelerometer recordings and body composition analyses using bioelectrical impedance. Other new assessments include cognitive and physical testing in old age, fecal sampling for microbiome studies, and metabolomics and proteomics analyses for deeper molecular phenotyping. With available genotype information, analyses are expanded to e.g. genome-wide association studies and Mendelian randomization.

\section{Who is in the cohort?}

In Nord-Trøndelag, all residents aged $\geq 20$ years at the estimated time of survey participation were invited to HUNT4 between 29 August 2017 and 23 February 2019 (the HUNT4-N Survey). Out of 103800 invitees, 56042 (54.0\%) participated, defined as returning the main questionnaire. Participation across the HUNT1-HUNT4 surveys is shown in Figure 1. In Sør-Trøndelag, all residents aged $\geq 18$ years were invited to the HUNT4-S Survey and 107711 (42.6\%) participated out of 252991 invitees. HUNT4-S consisted of two parts: 1745 residents $\geq 70$ years of age in districts of Trondheim municipality took part in an examination between 26 Oct 2018 and 12 Jun 2019, and the remaining took part in a questionnaire survey between 3 Oct 2019 and 19 Nov 2019. 
medRxiv preprint doi: https://doi.org/10.1101/2021.10.12.21264858; this version posted October 29, 2021. The copyright holder for this preprint (which was not certified by peer review) is the author/funder, who has granted medRxiv a license to display the preprint in

All rights reserved. No reuse allowed without permission.

Characteristics of HUNT4 participants are given in Table 1. Participation in HUNT4 differed by age, being highest in the age groups $40-79$ years, and also slightly differed by marital status and urban vs. rural residency (Table 2). Attrition from HUNT3 to HUNT4 was highest in older adults and was also moderately higher among people with chronic diseases, poor self-rated health, or who were smokers (Supplementary Table S2). Questionnaire surveys were performed among nonparticipants of HUNT4-N and previous HUNT participants who were not invited to HUNT4-N because they had emigrated from the study area (Table 3, Supplementary Table S3). Those who had emigrated reported lower BMI, more physical activity, less smoking and better self-rated health and more frequent alcohol intake than both participants and nonparticipants. The nonparticipants had less healthy lifestyle and lower self-reported health and higher proportion of cardiovascular diseases, chronic obstructive pulmonary disease, diabetes and antihypertensive medication use.

\section{What has been measured?}

Similar to previous HUNT surveys, HUNT4-N consisted of questionnaires, a short interview, clinical examination, and biological sampling, and was conducted by trained health professionals at examination stations in each of 23 municipalities in Nord-Trøndelag. HUNT4-S was mainly a webbased questionnaire survey (except for the examination of 1745 residents $\geq 70$ years of age in Trondheim), but printed questionnaires were sent on request and to older adults. The HUNT4 questionnaires covered a broad range of topics including socio-economic conditions, health-related behaviors, symptoms, conditions and diseases, as described in Table 3. Selected HUNT4-N participants were also asked to complete questionnaires related to specific health topics, and a $15 \%$ random sample aged 20-69 years was invited to complete a web-based food frequency questionnaire. $^{5}$

An overview of HUNT4 measurements, performed as part of the main HUNT4 examination or as ancillary data collections, is provided in Table 3. New aspects of the clinical examination in HUNT4-N compared to previous HUNT surveys included detailed body composition analysis using 
medRxiv preprint doi: https://doi.org/10.1101/2021.10.12.21264858; this version posted October 29, 2021. The copyright holder for this preprint (which was not certified by peer review) is the author/funder, who has granted medRxiv a license to display the preprint in All rights reserved. No reuse allowed without permission.

bioelectrical impedance (InBody 770, Cerritos, CA, USA), a one-week accelerometer recording (AX3, Axivity Ltd., Newcastle, UK), and physical and cognitive testing (Short Physical Performance Battery (SPPB), grip strength and Montreal Cognitive Assessment, MoCA; participants $\geq 70$ years of age). Blood pressure, pulse and peripheral capillary oxygen saturation were recorded three times at oneminute intervals using Dinamap CARESCAPE V100 (GE Healthcare, Chicago, Illinois, USA). Oral health clinical and radiographic examinations (Planmeca ProOne (orthopantomogram) and Planmeca Intra / Prostyle Intra with ProSensor HD (bitewing), Helsinki, Finland), hearing test (air-conduction puretone audiometry at $0.25-8 \mathrm{kHz}$ according to ISO $8253-1$ using Interacoustics audiometers type AD629 with TDH-39P supra-aural audiometric earphones) and spirometry (Jaeger Masterscope spirometers, JLAB version latest upgrade 2016, CareFusion, Würzburg, Germany) were performed in selected samples, and other tests have subsequently been performed in subgroups. All participants provided blood samples drawn in a non-fasting state between $9 \mathrm{am}$ and $8 \mathrm{pm}$ and time since last meal was recorded. Biological sampling at the field stations included blood, urine and saliva, while feces kits were returned in pre-paid envelopes. Biologic material was handled at the field stations according to appropriate standards and transported to the biobank every evening in a cold chain. For all participants, two blood tubes were delivered at the laboratory of Levanger Hospital, Nord-Trøndelag Hospital Trust the next day for immediate analyses or transport to other laboratories. New analyses in blood included hemoglobin ( $\mathrm{Hb})$ and blood cell counts, $\mathrm{HbA1c}$ and phosphatidylethanol (PEth, an indicator of alcohol intake). Three blood tubes were aliquoted and stored in automated freezers in HUNT Biobank.

Since the publication of the original cohort profile in $2013,{ }^{3}$ new analyses of biological material stored in HUNT Biobank include the genotyping of 70517 participants of HUNT2 or HUNT3, genotyping of 18722 additional participants of HUNT4-N (details on genotyping and imputation will be described in a separate paper), and SomaLogic's SomaScan proteomics analyses ${ }^{6}$ and measurements of vitamin $D^{7}$ and troponin $I^{8}$ in subsamples. 
medRxiv preprint doi: https://doi.org/10.1101/2021.10.12.21264858; this version posted October 29, 2021. The copyright holder for this preprint (which was not certified by peer review) is the author/funder, who has granted medRxiv a license to display the preprint in

All rights reserved. No reuse allowed without permission.

\section{What has it found? Key findings and publications}

In Table 1, we present descriptive characteristics of the HUNT4-N and HUNT4-S participants, including prevalence estimates of a range of chronic conditions and diseases. The longitudinal nature of HUNT enables analyses of long-term population changes in health-related factors. For example, comparison of HUNT4-N with previous HUNT surveys shows how the prevalence of smoking, high blood pressure and atherogenic lipid levels has declined from the 1980 s until now, whereas the prevalence of obesity and diabetes has increased (Figure 2, Supplementary Table S4). Although the prevalence of diabetes has increased, HbA1c measurements in HUNT4 indicate that the current prevalence of undiagnosed diabetes is low. ${ }^{9}$ The prevalence of tension-type headache has increased, whereas migraine and medication overuse headache have become less common, ${ }^{10}$ as has hearing impairment. ${ }^{11}$ Information from HUNT4 has further enabled prevalence estimates of dementia, mild cognitive impairment, ${ }^{12}$ periodontitis ${ }^{13}$ and depression and anxiety symptoms, ${ }^{14}$ and estimation of the longitudinal decline in $\mathrm{VO}_{2 \text { peak. }}{ }^{15}$ Analyses of HUNT4 have further shown that shift work is associated with higher levels of C-reactive protein and chronic musculoskeletal pain, ${ }^{16}$ and that cognitive impairment is associated with lower physical performance. ${ }^{17}$

The new focus on genetic and molecular epidemiology has resulted in e.g. genome-wide association studies (GWAS) identifying new genetic variants associated with atrial fibrillation, ${ }^{18}$ serum lipids, ${ }^{19}$ thyroid stimulating hormone $(\mathrm{TSH})^{20}$ and bone mineral density. ${ }^{21}$ Mendelian randomization studies have examined the causal associations between serum lipids and kidney function ${ }^{22}$ and provided support to the causal role of smoking heaviness on mortality, ${ }^{23}$ of higher body mass on psoriasis ${ }^{24}$ and bloodstream infections, ${ }^{25}$ and of PCSK9 on serum cholesterol and coronary heart disease. ${ }^{26}$ Anthropometric measures spanning six decades have demonstrated how body mass index (BMI) increases more strongly in genetically predisposed individuals during transition to a more obesogenic environment. ${ }^{27,28}$ The predictive value of circulating proteins on secondary cardiovascular events has been examined using proteomics analyses. ${ }^{6}$ The large number of relatives participating in HUNT has enabled within-family studies. Parent-offspring analyses have 
medRxiv preprint doi: https://doi.org/10.1101/2021.10.12.21264858; this version posted October 29, 2021. The copyright holder for this preprint (which was not certified by peer review) is the author/funder, who has granted medRxiv a license to display the preprint in

All rights reserved. No reuse allowed without permission.

suggested that maternal intrauterine environment, as proxied by maternal SNPs that influence offspring birthweight, is unlikely to be a major determinant of adverse cardiometabolic outcomes in population-based samples of offspring. ${ }^{29}$ Within-family Mendelian randomization analyses have enabled correction for familial biases in e.g. studies of the effects of height and body mass on educational attainment. ${ }^{30}$ Supplementary Table S5 provides examples of studies showing how HUNT data have been used across a range of health topics since the original cohort profile was published in 2013.

\section{What are the main strengths and weaknesses?}

HUNT is suitable for longitudinal studies due to the long-term follow-up with repeated measurements since the 1980s, low migration, and available valid information on migration and deaths from the National Population Register. The HUNT surveys cover a broad range of healthrelated topics, and many questionnaire items have been kept unchanged across the surveys to enable longitudinal comparisons. Quality-controlled HUNT data are stored at the HUNT Databank and biological material is stored in the state-of-the-art HUNT Biobank at the HUNT Research Centre, Levanger. The HUNT participants have consented to linkage to the many high-quality health and administrative registries in Norway, and to information from medical records. Such linkages can be reliably made using the national identification numbers allocated to all Norwegian residents and means that prospectively recorded information on health outcomes can be obtained also for participants who do not attend subsequent HUNT surveys. The ethnically homogenous population limits the generalizability to people of non-European ancestry.

As the HUNT Study has invited the entire population in the area over decades, the study population includes many family members, both siblings and across generations, and is therefore suitable for within-family studies. A particular asset compared with many other studies is available offspring information in adult age. ${ }^{31-33}$ The study population has cryptic relatedness that may have to 
medRxiv preprint doi: https://doi.org/10.1101/2021.10.12.21264858; this version posted October 29, 2021. The copyright holder for this preprint (which was not certified by peer review) is the author/funder, who has granted medRxiv a license to display the preprint in All rights reserved. No reuse allowed without permission.

be considered in the analytical approach of e.g. GWAS but is quite outbred with a mean inbreeding coefficient $^{34}$ of 0.0024 (calculated using KING software ${ }^{35}$ ).

The relatively high participation indicates a generally lower concern for selection bias. Nevertheless, attrition from HUNT3 to HUNT4 was somewhat higher among participants with chronic diseases or other indices of ill health, and lifestyle differed among nonparticipants and migrants compared with participants of HUNT4. To inform about selective participation by ill health among all HUNT4 invitees, we also examined primary health care diagnostic codes across a range of diseases, as well as primary health care utilization, for HUNT4 invitees and participants recorded during the calendar year 2017 (for HUNT4-N) or 2019 (for HUNT4-S). The proportion being assigned each diagnostic code generally did not differ substantially between participants and invitees, but results vary between diagnoses as detailed in Supplementary Table S6. For example, a dementia diagnosis was less often recorded among participants than among invitees. General practice visits were more frequent among participants than nonparticipants at ages $>80$ years. In contrast, home nursing and nursing home residency were more common among nonparticipants (Supplementary Figure S1).

To evaluate the quality of the self-report of conditions in HUNT4, we compared the selfreported information to diagnostic codes recorded in the local or regional hospitals and on general practitioners' reimbursement forms. Compared to these diagnoses as a reference standard, the sensitivity, specificity and predictive values of the self-reported information varied across diagnoses in both HUNT4-N (Supplementary Table S7) and HUNT4-S (Supplementary Table S8). Of note, the diagnostic codes may be inaccurate and do not constitute a definite reference standard. For example, in lack of a more suitable diagnostic code, a disease diagnosis may likely be reported on the reimbursement form by a general practitioner if a patient comes for testing for that disease, even if the disease was not confirmed. In-depth validity studies have been conducted for self- 
medRxiv preprint doi: https://doi.org/10.1101/2021.10.12.21264858; this version posted October 29, 2021. The copyright holder for this preprint (which was not certified by peer review) is the author/funder, who has granted medRxiv a license to display the preprint in

All rights reserved. No reuse allowed without permission.

reported headache ${ }^{36}$ and insomnia ${ }^{37}$ in HUNT4. Validity studies of self-report of e.g. diabetes, ${ }^{38}$ psoriasis $^{39}$ and atrial fibrillation ${ }^{40}$ have been performed after previous HUNT surveys.

\section{Can I get hold of the data? Where can I find out more?}

Researchers affiliated to a Norwegian research institution can apply for HUNT data access from HUNT Research Centre (www.ntnu.edu/hunt) if they have obtained project approval from the Regional Committee for Medical and Health Research Ethics (REC). Researchers not affiliated to a Norwegian research institution should collaborate with and apply through a Norwegian principal investigator. Information on the application and conditions for data access is available at www.ntnu.edu/hunt/data. The HUNT Databank website provides a detailed overview of the available variables in HUNT (www.ntnu.edu/hunt/databank). Certain data from ancillary HUNT projects may be subject to a time-limited exclusivity provided to the researchers who have financed and conducted the data collection. Biologic material is available for analyses, information on procedures is found at the HUNT Biobank website (https://www.ntnu.edu/hunt/hunt-biobank). Data from the health registries are not kept by HUNT; instead, linkages between HUNT and registry data have to be made for each research project and require that the principal investigator has obtained project-specific approval for such linkage by REC and each registry owner.

\section{Acknowledgements}

The Trøndelag Health Study (HUNT) is a collaboration between HUNT Research Centre (Faculty of Medicine and Health Sciences, NTNU, Norwegian University of Science and Technology), Trøndelag County Council, Central Norway Regional Health Authority, and the Norwegian Institute of Public Health. We thank the population of Trøndelag for their willingness to contribute with important data and biologic material, and politicians and administrations in all municipalities for positive attitude and support of logistics. We thank the administrative staff at HUNT Research Centre for comprehensive contribution to the planning, performance, collection and storage of data and 
medRxiv preprint doi: https://doi.org/10.1101/2021.10.12.21264858; this version posted October 29, 2021. The copyright holder for this preprint (which was not certified by peer review) is the author/funder, who has granted medRxiv a license to display the preprint in

All rights reserved. No reuse allowed without permission.

biologic material. For this Cohort Profile Update, Nord-Trøndelag Hospital Trust provided diagnostic codes from Nord-Trøndelag Hospital Trust and St. Olavs hospital, and the Norwegian Directorate of Health provided data from the KUHR database and the Norwegian Registry for Primary Health Care. The interpretation and reporting of these data are the sole responsibility of the authors, and no endorsement by the Norwegian Registry for Primary Health Care is intended nor should be inferred. The work presented in this Cohort Profile Update was approved by the Mid-Norway Regional Committee for Medical and Health Research Ethics (REK midt 67445).

\section{References:}

1. Holmen J, Midthjell K, Bjartveit K, et al. The Nord-Trøndelag Health Survey 1984-1986.

Purpose, background and methods. Participation, non-participation and frequency distributions.

Report no 4. Verdal: Statens Institutt for folkehelse, Senter for samfunnsmedisinsk forskning, 1990.

2. Holmen J, Midthjell K, Krüger $\varnothing$, et al. The Nord-Trøndelag Health Study 1995-97 (HUNT 2):

Objectives, contents, methods and participation. Norsk Epidemiologi 2003;13:19-32.

3. Krokstad S, Langhammer A, Hveem K, et al. Cohort Profile: the HUNT Study, Norway. Int J Epidemiol 2013;42:968-77.

4. Holmen TL, Bratberg G, Krokstad S, et al. Cohort profile of the Young-HUNT Study, Norway: a population-based study of adolescents. Int J Epidemiol 2014;43:536-44.

5. Carlsen MH, Lillegaard IT, Karlsen A, Blomhoff R, Drevon CA, Andersen LF. Evaluation of energy and dietary intake estimates from a food frequency questionnaire using independent energy expenditure measurement and weighed food records. Nutr J 2010;9:37.

6. Ganz P, Heidecker B, Hveem K, et al. Development and Validation of a Protein-Based Risk Score for Cardiovascular Outcomes Among Patients With Stable Coronary Heart Disease. JAMA 2016;315:2532-41. 
medRxiv preprint doi: https://doi.org/10.1101/2021.10.12.21264858; this version posted October 29,2021 . The copyright holder for this preprint (which was not certified by peer review) is the author/funder, who has granted medRxiv a license to display the preprint in All rights reserved. No reuse allowed without permission.

7. Larose TL, Chen Y, Camargo CA, Jr., Langhammer A, Romundstad P, Mai XM. Factors associated with vitamin D deficiency in a Norwegian population: the HUNT Study. J Epidemiol Community Health 2014;68:165-70.

8. Lyngbakken MN, Rosjo H, Holmen OL, Dalen H, Hveem K, Omland T. Temporal Changes in Cardiac Troponin I Are Associated with Risk of Cardiovascular Events in the General Population: The Nord-Trondelag Health Study. Clin Chem 2019;65:871-81.

9. Stene LC, Ruiz PL, Asvold BO, et al. How many people have diabetes in Norway in 2020? Tidsskr Nor Laegeforen 2020;140.

10. Hagen K, Stovner L, Zwart JA. Time trends of major headache diagnoses and predictive factors. Data from three Nord-Trondelag health surveys. J Headache Pain 2020; 21:24.

11. Engdahl B, Strand BH, Aarhus L. Better Hearing in Norway: A Comparison of Two HUNT Cohorts 20 Years Apart. Ear Hear 2020;42:42-52.

12. Gjora L, Strand BH, Bergh S, et al. Current and Future Prevalence Estimates of Mild Cognitive Impairment, Dementia, and Its Subtypes in a Population-Based Sample of People 70 Years and Older in Norway: The HUNT Study. J Alzheimers Dis 2021;79:1213-26.

13. Stodle IH, Verket A, Hovik H, Sen A, Koldsland OC. Prevalence of periodontitis based on the 2017 classification in a Norwegian population: The HUNT study. J Clin Periodontol 2021;48:1189-99.

14. Bojanic I, Sund ER, Sletvold H, Bjerkeset O. Prevalence trends of depression and anxiety symptoms in adults with cardiovascular diseases and diabetes 1995-2019: The HUNT studies, Norway. BMC Psychol 2021;9:130.

15. Letnes JM, Dalen H, Aspenes ST, Salvesen O, Wisloff U, Nes BM. Age-related change in peak oxygen uptake and change of cardiovascular risk factors. The HUNT Study. Prog Cardiovasc Dis 2020;63:730-7.

16. Matre D, Christensen JO, Mork PJ, Ferreira P, Sand T, Nilsen KB. Shift work, inflammation and musculoskeletal pain-The HUNT Study. Occup Med (Lond) 2021. 
medRxiv preprint doi: https://doi.org/10.1101/2021.10.12.21264858; this version posted October 29, 2021. The copyright holder for this preprint (which was not certified by peer review) is the author/funder, who has granted medRxiv a license to display the preprint in

All rights reserved. No reuse allowed without permission.

17. Sverdrup K, Selbaek G, Bergh S, et al. Physical performance across the cognitive spectrum and between dementia subtypes in a population-based sample of older adults: The HUNT study. Arch Gerontol Geriatr 2021;95:104400.

18. Nielsen JB, Thorolfsdottir RB, Fritsche LG, et al. Biobank-driven genomic discovery yields new insight into atrial fibrillation biology. Nat Genet 2018;50:1234-9.

19. Nielsen JB, Rom O, Surakka I, et al. Loss-of-function genomic variants highlight potential therapeutic targets for cardiovascular disease. Nat Commun 2020;11:6417.

20. Zhou W, Brumpton B, Kabil O, et al. GWAS of thyroid stimulating hormone highlights pleiotropic effects and inverse association with thyroid cancer. Nat Commun 2020;11:3981.

21. Surakka I, Fritsche LG, Zhou W, et al. MEPE loss-of-function variant associates with decreased bone mineral density and increased fracture risk. Nat Commun 2020;11:4093.

22. Rasheed H, Zheng J, Rees J, et al. The causal effects of serum lipids and apolipoproteins on kidney function: multivariable and bidirectional Mendelian-randomization analyses. Int J Epidemiol 2021.

23. Vie GA, Wootton RE, Bjorngaard JH, et al. The effect of smoking intensity on all-cause and cause-specific mortality-a Mendelian randomization analysis. Int J Epidemiol 2019;48:1438-46.

24. Budu-Aggrey A, Brumpton B, Tyrrell J, et al. Evidence of a causal relationship between body mass index and psoriasis: A mendelian randomization study. PLoS Med 2019;16:e1002739.

25. Rogne $T$, Solligard E, Burgess $\mathrm{S}$, et al. Body mass index and risk of dying from a bloodstream infection: A Mendelian randomization study. PLoS Med 2020;17:e1003413.

26. Brumpton BM, Fritsche LG, Zheng J, et al. Variation in Serum PCSK9 (Proprotein Convertase Subtilisin/Kexin Type 9), Cardiovascular Disease Risk, and an Investigation of Potential Unanticipated Effects of PCSK9 Inhibition. Circ Genom Precis Med 2019;12:e002335.

27. Brandkvist M, Bjorngaard JH, Odegard RA, Asvold BO, Sund ER, Vie GA. Quantifying the impact of genes on body mass index during the obesity epidemic: longitudinal findings from the HUNT Study. BMJ 2019;366:14067. 
medRxiv preprint doi: https://doi.org/10.1101/2021.10.12.21264858; this version posted October 29, 2021. The copyright holder for this preprint (which was not certified by peer review) is the author/funder, who has granted medRxiv a license to display the preprint in

All rights reserved. No reuse allowed without permission.

28. Brandkvist M, Bjorngaard JH, Odegard RA, et al. Genetic associations with temporal shifts in obesity and severe obesity during the obesity epidemic in Norway: A longitudinal population-based cohort (the HUNT Study). PLoS Med 2020;17:e1003452.

29. Moen GH, Brumpton B, Willer C, et al. Mendelian randomization study of maternal influences on birthweight and future cardiometabolic risk in the HUNT cohort. Nat Commun 2020;11:5404.

30. Brumpton B, Sanderson E, Heilbron K, et al. Avoiding dynastic, assortative mating, and population stratification biases in Mendelian randomization through within-family analyses. Nat Commun 2020;11:3519.

31. Alsnes IV, Vatten L, Fraser A, et al. Hypertension in Pregnancy and Offspring Cardiovascular Risk in Young Adulthood: Prospective and Sibling Studies in the HUNT Study (Nord-Trondelag Health Study) in Norway. Hypertension 2017;69:591-8.

32. Carslake D, Davey Smith G, Gunnell D, Davies N, Nilsen TIL, Romundstad P. Confounding by ill health in the observed association between BMI and mortality: evidence from the HUNT Study using offspring BMI as an instrument. Int J Epidemiol 2018;47:760-70.

33. Zadro JR, Nilsen TIL, Shirley D, Amorim AB, Ferreira PH, Mork PJ. Parental chronic widespread pain and the association with chronic widespread pain in adult offspring: Family-linkage data from the Norwegian HUNT Study. Eur J Pain 2018.

34. Clark DW, Okada Y, Moore KHS, et al. Associations of autozygosity with a broad range of human phenotypes. Nat Commun 2019;10:4957.

35. Manichaikul A, Mychaleckyj JC, Rich SS, Daly K, Sale M, Chen WM. Robust relationship inference in genome-wide association studies. Bioinformatics 2010;26:2867-73.

36. Hagen K, Asberg AN, Uhlig BL, Tronvik E, Brenner E, Sand T. The HUNT4 study: the validity of questionnaire-based diagnoses. J Headache Pain 2019;20:70.

37. Filosa J, Omland PM, Langsrud K, et al. Validation of insomnia questionnaires in the general population: The Nord-Trondelag Health Study (HUNT). J Sleep Res 2021;30:e13222. 
medRxiv preprint doi: https://doi.org/10.1101/2021.10.12.21264858; this version posted October 29, 2021. The copyright holder for this preprint (which was not certified by peer review) is the author/funder, who has granted medRxiv a license to display the preprint in All rights reserved. No reuse allowed without permission.

38. Midthjell K, Holmen J, Bjorndal A, Lund-Larsen G. Is questionnaire information valid in the study of a chronic disease such as diabetes? The Nord-Trondelag diabetes study. J Epidemiol Community Health 1992;46:537-42.

39. Modalsli EH, Snekvik I, Asvold BO, Romundstad PR, Naldi L, Saunes M. Validity of SelfReported Psoriasis in a General Population: The HUNT Study, Norway. J Invest Dermatol 2016;136:323-5.

40. Malmo V, Langhammer A, Bonaa KH, Loennechen JP, Ellekjaer H. Validation of self-reported and hospital-diagnosed atrial fibrillation: the HUNT study. Clin Epidemiol 2016;8:185-93. 
medRxiv preprint doi: https://doi.org/10.1101/2021.10.12.21264858; this version posted October 29, 2021. The copyright holder for this preprint (which was not certified by peer review) is the author/funder, who has granted medRxiv a license to display the preprint in perpetuity.

All rights reserved. No reuse allowed without permission.

Table 1. Characteristics of participants in the HUNT4 Survey (HUNT4-N and HUNT4-S), reported as percentages ${ }^{\mathrm{a}}$ unless otherwise noted.

\begin{tabular}{|c|c|c|c|c|}
\hline \multirow[t]{2}{*}{ Characteristics } & \multicolumn{2}{|l|}{ HUNT4-N ${ }^{b}$} & \multicolumn{2}{|l|}{ HUNT4-S ${ }^{c}$} \\
\hline & $\begin{array}{c}\text { Women } \\
(n=30574)\end{array}$ & $\begin{array}{c}\text { Men } \\
(n=25468)\end{array}$ & $\begin{array}{c}\text { Women } \\
(n=61066)\end{array}$ & $\begin{array}{c}\text { Men } \\
(n=46645)\end{array}$ \\
\hline Age (years), mean (SD, range) & $\begin{array}{l}53.9(17.8 \\
19-102)^{d}\end{array}$ & $\begin{array}{l}54.8(17.3 \\
19-101)^{d}\end{array}$ & $\begin{array}{c}49.9(17.9, \\
18-105)\end{array}$ & $\begin{array}{l}52.2(17.7 \\
18-100)\end{array}$ \\
\hline \multicolumn{5}{|l|}{ Age groups (years) } \\
\hline$<30$ & 11.9 & 11.0 & 16.8 & 13.7 \\
\hline $30-39$ & 12.7 & 11.3 & 15.7 & 13.6 \\
\hline $40-49$ & 16.6 & 15.4 & 17.2 & 16.7 \\
\hline $50-59$ & 19.0 & 19.4 & 19.2 & 19.4 \\
\hline $60-69$ & 18.8 & 21.3 & 16.1 & 18.6 \\
\hline $70-79$ & 14.2 & 15.6 & 10.2 & 13.2 \\
\hline $80-89$ & 5.6 & 5.2 & 3.9 & 4.4 \\
\hline$\geq 90$ & 1.2 & 0.7 & 0.8 & 0.5 \\
\hline \multicolumn{5}{|l|}{ Years of education ${ }^{\mathrm{e}}$} \\
\hline$\leq 10$ & 13.1 & 10.0 & 7.9 & 6.5 \\
\hline $11-13$ & 44.4 & 55.3 & 39.2 & 44.2 \\
\hline$\geq 14$ & 42.5 & 34.7 & 52.9 & 49.3 \\
\hline Married, registered partner or cohabitant & 71.5 & 77.4 & 67.5 & 72.7 \\
\hline Living in urban constituency & 39.6 & 37.3 & 56.3 & 56.3 \\
\hline Good or very good self-rated health & 73.6 & 78.6 & 74.2 & 80.5 \\
\hline \multicolumn{5}{|l|}{ Daily smoking } \\
\hline Never & 56.1 & 55.9 & 71.2 & 68.9 \\
\hline Former & 34.3 & 37.1 & 21.3 & 25.2 \\
\hline Current & 9.6 & 7.0 & 7.5 & 5.9 \\
\hline Alcohol, units per week (median, IQR) ${ }^{f}$ & $1(0-2.5)$ & $2.5(1-4.5)$ & $1(0-3)$ & $3(1-5.5)$ \\
\hline \multicolumn{5}{|l|}{ Frequency of physical exercise } \\
\hline$\leq$ once/week & 32.4 & 40.6 & 28.7 & 34.0 \\
\hline 2-3 times/week & 43.9 & 39.0 & 42.4 & 40.3 \\
\hline Almost every day & 23.7 & 20.4 & 29.0 & 25.7 \\
\hline \multicolumn{5}{|l|}{$\begin{array}{l}\text { Self-reported history of current or } \\
\text { previous disease }\end{array}$} \\
\hline $\begin{array}{l}\text { Coronary heart disease (myocardial } \\
\text { infarction or angina pectoris) }\end{array}$ & 3.5 & 8.6 & 3.2 & 8.3 \\
\hline Atrial fibrillation & 4.0 & 7.0 & 4.3 & 7.9 \\
\hline Stroke & 2.9 & 4.1 & 2.1 & 3.3 \\
\hline Asthma & 12.5 & 11.6 & 14.4 & 13.1 \\
\hline COPD & 2.6 & 3.3 & 1.9 & 2.6 \\
\hline Diabetes & 5.2 & 7.1 & 3.9 & 6.1 \\
\hline Hypo- or hyperthyroidism & 12.1 & 3.3 & 12.1 & 3.7 \\
\hline Cancer & 7.9 & 8.0 & 7.8 & 8.1 \\
\hline $\begin{array}{l}\text { Sought health care for mental health } \\
\text { problems }\end{array}$ & 21.6 & 12.2 & 32.9 & 19.5 \\
\hline \multicolumn{5}{|l|}{ Current drug treatment } \\
\hline Antihypertensive medication & 21.4 & 25.6 & 15.6 & 21.8 \\
\hline Lipid-lowering medication & 14.3 & 18.8 & 9.9 & 17.2 \\
\hline Medication for asthma or COPD & 8.3 & 7.3 & 7.5 & 6.6 \\
\hline Medication for anxiety or depression & 8.9 & 4.7 & 6.6 & 3.9 \\
\hline
\end{tabular}


medRxiv preprint doi: https://doi.org/10.1101/2021.10.12.21264858; this version posted October 29, 2021. The copyright holder for this preprint (which was not certified by peer review) is the author/funder, who has granted medRxiv a license to display the preprint in perpetuity.

All rights reserved. No reuse allowed without permission.

Medication for thyroid dysfunction

Visit to a general practitioner during the last 12 months

Admitted to hospital during the last 12

months

Body mass index ${ }^{g}\left(\mathrm{~kg} / \mathrm{m}^{2}\right)$, mean (SD)

Body mass index categories $\left(\mathrm{kg} / \mathrm{m}^{2}\right)$

$<18.5$

18.5-24.9

25.0-29.9

$\geq 30.0$

Systolic blood pressure ${ }^{\mathrm{h}}(\mathrm{mmHg})$, mean

(SD)

Diastolic blood pressure ${ }^{\mathrm{h}}(\mathrm{mmHg})$, mean

(SD)

Low-density lipoprotein cholesterol ${ }^{i}$

(mmol/l), mean (SD)

Estimated glomerular filtration rate $\mathrm{j}^{\mathrm{j}}<60$ $\mathrm{ml} / \mathrm{min} / 1.73 \mathrm{~m}^{2}$

$\begin{array}{cccc}9.5 & 2.7 & 8.8 & 2.6 \\ 85.9 & 77.7 & 86.2 & 78.1\end{array}$

$\begin{array}{llll}14.1 & 12.4 & \text { NA } & \text { NA }\end{array}$

$26.9(5.1) \quad 27.6(4.2) \quad 25.8(4.9) \quad 26.7(4.1)$

$\begin{array}{llll}1.5 & 0.4 & 1.7 & 0.5\end{array}$

$\begin{array}{llll}38.2 & 27.1 & 48.6 & 36.7\end{array}$

$\begin{array}{llll}36.3 & 48.3 & 32.6 & 45.7\end{array}$

$\begin{array}{llll}24.1 & 24.2 & 17.1 & 17.1\end{array}$

$126.1(19.4) \quad 131.0(16.9) \quad$ NA $\quad$ NA

$\begin{array}{llll}70.8(9.4) & 76.0(10.3) & N A & \text { NA }\end{array}$

$3.25(0.97) \quad 3.15(0.96) \quad N A \quad N A$

$\begin{array}{llll}6.6 & 6.2 & N A & N A\end{array}$

Abbreviations: COPD, chronic obstructive pulmonary disease; IQR, inter-quartile range; SD, standard deviation

a Calculated among people with valid information, which ranges from $89 \%$ to $100 \%$ for individual items

${ }^{b}$ The survey was conducted in Nord-Trøndelag between 29 August 2017 and 23 February 2019 (the survey includes a pilot study performed in May 2017). Characteristics are presented for the 56042 individuals who participated in HUNT4-N by returning the main questionnaire. In addition, 897 individuals took part in the clinical examination, but did not return the questionnaire; these individuals were more often older adults included in the HUNT70+ study part that will be described in a separate paper.

c The survey was conducted in Sør-Trøndelag as a questionnaire survey between 3 October and 19 November 2019 (105 966 participants) or as an examination among residents $\geq 70$ years in districts of Trondheim municipality between 26 October 2018 and 12 June 2019 (1745 participants). The 252991 invitees to HUNT4-S include all adult residents of S $\varnothing$-Trøndelag, except former Nord-Trøndelag residents who had moved to S $\varnothing$ rTrøndelag after previously participating in HUNT and were instead invited to an emigrant survey.

${ }^{d}$ All residents aged $\geq 20$ years at the estimated time of survey participation were invited, and some were aged 19 years at the date of participation.

e Years of education based on self-reported level of education: primary school $\leq 10$ years; academic or vocational school/apprentice $11-13$ years; and university college or university $\geq 14$ years.

f Units (12.8 g alcohol) calculated based on the self-reported usual number of glasses of beer/wine/liquor per 2 weeks or, if that information was missing, estimated from the reported frequency of alcohol consumption during the last year.

$\mathrm{g}$ For participants of the questionnaire survey in HUNT4-S, this was calculated from self-reported weight and height

${ }^{\mathrm{h}}$ Mean of the $2^{\text {nd }}$ and $3^{\text {rd }}$ measurements. For $0.4 \%$ of participants who had only 2 valid blood pressure measurements, we used the $2^{\text {nd }}$ measurement.

' Estimated using the equation developed by Sampson M et al., JAMA Cardiol. 2020;5(5):540-548.

j Estimated using the Chronic Kidney Disease Epidemiology collaboration (CKD-EPI) equation 
Table 2. Relative probability of participation in HUNT4-N and HUNT4-S by sociodemographic characteristics.

\begin{tabular}{|c|c|c|c|c|c|c|c|c|}
\hline \multirow{3}{*}{ Characteristics } & \multicolumn{4}{|l|}{ HUNT4-N } & \multicolumn{4}{|l|}{ HUNT4-S } \\
\hline & \multicolumn{2}{|l|}{ Women } & \multicolumn{2}{|l|}{ Men } & \multicolumn{2}{|l|}{ Women } & \multicolumn{2}{|l|}{ Men } \\
\hline & $\begin{array}{c}\text { Participants, } \\
n(\%)^{\mathrm{a}}\end{array}$ & $\begin{array}{c}\text { Relative } \\
\text { probability }^{b} \\
(95 \% \mathrm{Cl})\end{array}$ & $\begin{array}{c}\text { Participants, } \\
n(\%)^{\mathrm{a}}\end{array}$ & $\begin{array}{c}\text { Relative } \\
\text { probability }^{b} \\
(95 \% \mathrm{Cl})\end{array}$ & $\begin{array}{c}\text { Participants, } \\
n(\%)^{\mathrm{a}}\end{array}$ & $\begin{array}{c}\text { Relative } \\
\text { probability }^{b} \\
(95 \% \mathrm{Cl})\end{array}$ & $\begin{array}{c}\text { Participants, } \\
n(\%)^{\mathrm{a}}\end{array}$ & $\begin{array}{c}\text { Relative } \\
\text { probability }^{b} \\
(95 \% \mathrm{Cl})\end{array}$ \\
\hline $\begin{array}{l}\text { Total invited } \\
\text { population } \\
\text { Age (years) }\end{array}$ & $\begin{array}{c}30574 \\
(58.8 \%)\end{array}$ & & $\begin{array}{l}25468 \\
(49.1 \%)\end{array}$ & & $\begin{array}{c}61066 \\
(48.9 \%)\end{array}$ & & $\begin{array}{c}46645 \\
(36.4 \%)\end{array}$ & \\
\hline$<30$ & $\begin{array}{l}3643 \\
(43.5)\end{array}$ & $\begin{array}{c}1.00 \\
\text { (reference) }\end{array}$ & $\begin{array}{c}2811 \\
(31.0)\end{array}$ & $\begin{array}{c}1.00 \\
\text { (reference) }\end{array}$ & $\begin{array}{l}10289 \\
(38.4)\end{array}$ & $\begin{array}{c}1.00 \\
\text { (reference) }\end{array}$ & $\begin{array}{l}6396 \\
(21.6)\end{array}$ & $\begin{array}{c}1.00 \\
\text { (reference) }\end{array}$ \\
\hline $30-39$ & $\begin{array}{l}3870 \\
(52.5)\end{array}$ & $\begin{array}{c}1.21 \\
(1.17-1.25)\end{array}$ & $\begin{array}{c}2881 \\
(38.1)\end{array}$ & $\begin{array}{c}1.23 \\
(1.18-1.28)\end{array}$ & $\begin{array}{l}9591 \\
(46.3)\end{array}$ & $\begin{array}{c}1.20 \\
(1.18-1.23)\end{array}$ & $\begin{array}{l}6327 \\
(27.9)\end{array}$ & $\begin{array}{c}1.29 \\
(1.26-1.33)\end{array}$ \\
\hline $40-49$ & $\begin{array}{l}5087 \\
(59.1)\end{array}$ & $\begin{array}{c}1.36 \\
(1.32-1.40)\end{array}$ & $\begin{array}{l}3908 \\
(45.2)\end{array}$ & $\begin{array}{c}1.46 \\
(1.40-1.52)\end{array}$ & $\begin{array}{c}10532 \\
(52.9)\end{array}$ & $\begin{array}{c}1.38 \\
(1.35-1.40)\end{array}$ & $\begin{array}{l}7784 \\
(36.8)\end{array}$ & $\begin{array}{c}1.70 \\
(1.66-1.75)\end{array}$ \\
\hline $50-59$ & $\begin{array}{l}5817 \\
(65.7)\end{array}$ & $\begin{array}{c}1.51 \\
(1.47-1.56)\end{array}$ & $\begin{array}{l}4948 \\
(53.9)\end{array}$ & $\begin{array}{c}1.74 \\
(1.68-1.80)\end{array}$ & $\begin{array}{l}11728 \\
(59.5)\end{array}$ & $\begin{array}{c}1.55 \\
(1.52-1.58)\end{array}$ & $\begin{array}{l}9044 \\
(44.4)\end{array}$ & $\begin{array}{c}2.06 \\
(2.00-2.11)\end{array}$ \\
\hline $60-69$ & $\begin{array}{l}5745 \\
(69.9)\end{array}$ & $\begin{array}{c}1.61 \\
(1.56-1.65)\end{array}$ & $\begin{array}{l}5430 \\
(63.8)\end{array}$ & $\begin{array}{c}2.06 \\
(1.99-2.13)\end{array}$ & $\begin{array}{l}9851 \\
(59.3)\end{array}$ & $\begin{array}{c}1.54 \\
(1.51-1.57)\end{array}$ & $\begin{array}{l}8677 \\
(52.1)\end{array}$ & $\begin{array}{c}2.41 \\
(2.35-2.48)\end{array}$ \\
\hline $70-79$ & $\begin{array}{l}4329 \\
(67.8)\end{array}$ & $\begin{array}{c}1.56 \\
(1.51-1.61)\end{array}$ & $\begin{array}{c}3978 \\
(65.3)\end{array}$ & $\begin{array}{c}2.11 \\
(2.03-2.18)\end{array}$ & $\begin{array}{c}6253 \\
(47.5)\end{array}$ & $\begin{array}{c}1.24 \\
(1.21-1.26)\end{array}$ & $\begin{array}{l}6151 \\
(49.5)\end{array}$ & $\begin{array}{c}2.29 \\
(2.23-2.36)\end{array}$ \\
\hline $80-89$ & $\begin{array}{l}1725 \\
(54.1)\end{array}$ & $\begin{array}{c}1.25 \\
(1.20-1.30)\end{array}$ & $\begin{array}{c}1327 \\
(56.5)\end{array}$ & $\begin{array}{c}1.82 \\
(1.74-1.91)\end{array}$ & $\begin{array}{l}2357 \\
(38.3)\end{array}$ & $\begin{array}{c}1.00 \\
(0.96-1.03)\end{array}$ & $\begin{array}{l}2041 \\
(46.0)\end{array}$ & $\begin{array}{c}2.13 \\
(2.05-2.21)\end{array}$ \\
\hline$\geq 90$ & $\begin{array}{c}358 \\
(37.5)\end{array}$ & $\begin{array}{c}0.86 \\
(0.79-0.94)\end{array}$ & $\begin{array}{c}185 \\
(41.9)\end{array}$ & $\begin{array}{c}1.35 \\
(1.20-1.51)\end{array}$ & $\begin{array}{c}465 \\
(25.2)\end{array}$ & $\begin{array}{c}0.66 \\
(0.61-0.71)\end{array}$ & $\begin{array}{c}225 \\
(29.7)\end{array}$ & $\begin{array}{c}1.38 \\
(1.23-1.54)\end{array}$ \\
\hline $\begin{array}{l}\text { Marital status } \\
\text { Married or } \\
\text { registered partner }\end{array}$ & $\begin{array}{c}15184 \\
(66.5)\end{array}$ & $\begin{array}{c}1.00 \\
\text { (reference) }\end{array}$ & $\begin{array}{c}14092 \\
(60.3)\end{array}$ & $\begin{array}{c}1.00 \\
\text { (reference) }\end{array}$ & $\begin{array}{c}27230 \\
(55.7)\end{array}$ & $\begin{array}{c}1.00 \\
\text { (reference) }\end{array}$ & $\begin{array}{c}24033 \\
(47.2)\end{array}$ & $\begin{array}{c}1.00 \\
\text { (reference) }\end{array}$ \\
\hline
\end{tabular}




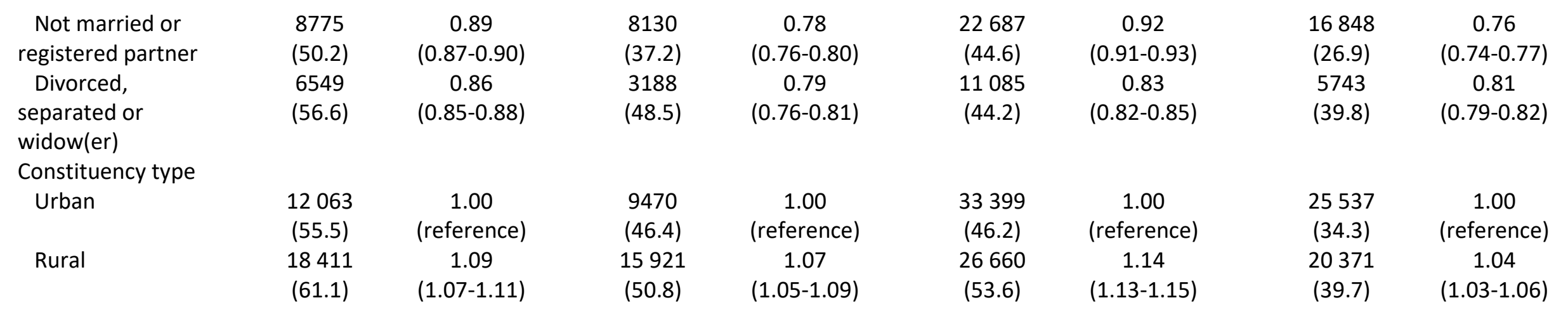

${ }^{a}$ Percentage among the total number of invitees in the category

${ }^{\mathrm{b}}$ Age-adjusted relative probability of participation 
Table 3. Content of the HUNT4-N and HUNT4-S surveys.

\begin{tabular}{|c|c|c|c|}
\hline $\begin{array}{l}\text { Study parts and } \\
\text { data collection } \\
\text { method }\end{array}$ & Selection criteria & $\begin{array}{l}\text { Participants, } n \\
\text { (\% of those } \\
\text { invited) }\end{array}$ & Content \\
\hline \multicolumn{4}{|c|}{ HUNT4-N (Nord-Trøndelag region) } \\
\hline \multicolumn{4}{|c|}{ Questionnaires (Q) } \\
\hline $\begin{array}{l}\text { Q1 Web/printed } \\
\text { Web }\end{array}$ & $\begin{array}{l}\text { All residents of Nord-Trøndelag aged } \\
\geq 20 \text { years. Answered prior to } \\
\text { attending the examination }\end{array}$ & $56042(54.0)$ & $\begin{array}{l}\text { Quality of life, diseases and illnesses, medication, health care } \\
\text { utilization, lifestyle, screen-based activity, growing up, } \\
\text { socioeconomics }\end{array}$ \\
\hline $\begin{array}{l}\text { Q2 Web/printed } \\
\text { Web }\end{array}$ & $\begin{array}{l}\text { All responders to Q1, answered at the } \\
\text { screening station or returned in pre- } \\
\text { paid envelopes }\end{array}$ & $42763(77.0)$ & $\begin{array}{l}\text { Social network, diet, broad range of symptoms, cultural activities, life } \\
\text { events, sexuality, work, pregnancies and birth control, activities of } \\
\text { daily living. Different questionnaires by sex and age }\end{array}$ \\
\hline $\begin{array}{l}\text { Q3 Arthritis } \\
\text { Printed }\end{array}$ & $\begin{array}{l}\text { Participants reporting 1) rheumatoid } \\
\text { arthritis or spondylarthritis, } 2 \text { ) joint } \\
\text { pain and psoriasis, and 3) random } 5 \% \\
\text { reporting joint pain but not psoriasis }\end{array}$ & 3775 (80.9) & $\begin{array}{l}\text { Diagnosis, family history, use of medication, symptom load, physical } \\
\text { function }\end{array}$ \\
\hline $\begin{array}{l}\text { Q3 Diabetes } \\
\text { Printed }\end{array}$ & Participants reporting diabetes & $2393(73.5)$ & $\begin{array}{l}\text { Age of onset, symptoms, use of medications, complications, } \\
\text { challenges }\end{array}$ \\
\hline Q3 Diet & $\begin{array}{l}15.4 \% \text { random sample among } \\
\text { participants } 20-69 \text { years }^{a}\end{array}$ & 5027 (58.9) & $\begin{array}{l}\text { FFQ assessing the habitual total dietary intake in adults, including } 281 \\
\text { questions about food items, meals and dietary supplements }\end{array}$ \\
\hline $\begin{array}{l}\text { Q3 CAM Printed } \\
\text { Pris }\end{array}$ & $\begin{array}{l}\text { Participants reporting use of CAM last } \\
12 \text { months }\end{array}$ & 4145 (78.7) & Type, frequency, effect of, and reasons for use of CAM \\
\hline $\begin{array}{l}\text { Q3 Oral Health } \\
\text { Printed }\end{array}$ & $\begin{array}{l}20 \% \text { random sample of HUNT4 } \\
\text { participants and participants in the } \\
\text { HUNT3 Dental Health Study }\end{array}$ & $7435(66.8)$ & $\begin{array}{l}\text { Use of dental services, oral hygiene habits, oral health-related quality } \\
\text { of life (OHIP-14) }\end{array}$ \\
\hline $\begin{array}{l}\text { Q Non- } \\
\text { participation } \\
\quad \text { Printed }\end{array}$ & $\begin{array}{l}\text { Anonymous questionnaire } \\
20 \% \text { random sample of } \\
\text { nonparticipants in HUNT4-N }\end{array}$ & 1320 (13.9) & Quality of life, lifestyle, diseases, and reasons for nonparticipation \\
\hline $\begin{array}{l}\text { Emigration } \\
\text { study }\end{array}$ & $\begin{array}{l}\text { All previous participants in HUNT1-3 } \\
\text { or Young-HUNT1-3 having moved out }\end{array}$ & $5219(35.8)$ & Similar to Q1 and Q2 \\
\hline Web & & & \\
\hline
\end{tabular}


of Nord-Trøndelag before invitation to

HUNT4-N

\begin{tabular}{|c|c|c|c|}
\hline \multicolumn{4}{|c|}{ At the examination stations } \\
\hline Interview & All participants & $53806(96.0)$ & Ethnicity, sources of subsistence, work, reproductive factors \\
\hline \multicolumn{4}{|l|}{ Clinical } \\
\hline \multirow[t]{2}{*}{ measurements } & All participants & $53816(96.0)$ & Blood pressure, pulse, peripheral oxygen saturation, height, weight \\
\hline & & $51477(91.9)^{b}$ & Body composition (bioelectrical impedance analysis) \\
\hline \multirow{2}{*}{$\begin{array}{l}\text { Physical activity } \\
\text { and sleep }\end{array}$} & All participants (if available sensors) & $31295(55.8)$ & Diary of time at work \\
\hline & & & Accelerometer sensors at the thigh and lower back for one week \\
\hline Oral health & $\begin{array}{l}20 \% \text { random sample of HUNT4 } \\
\text { participants and participants in the } \\
\text { HUNT3 Dental Health Study }{ }^{-c, d}\end{array}$ & $4933(67.0)$ & $\begin{array}{l}\text { Clinical examination (dental caries, periodontal status and oral } \\
\text { mucosa), radiographic examination (OPG and BW), saliva for } \\
\text { microbiome analysis }\end{array}$ \\
\hline Hearing & $\begin{array}{l}\text { All participants in larger } \\
\text { municipalities }^{d}\end{array}$ & $28411(83.5)$ & $\begin{array}{l}\text { Hearing test, questionnaire on hearing loss, exposure to noise, } \\
\text { tinnitus }\end{array}$ \\
\hline Lung study & $\begin{array}{l}10 \% \text { random sample and those } \\
\text { reporting symptoms, medication, or } \\
\text { diagnosis of obstructive lung disease } \\
\text { Age } 19-85 \text { years }\end{array}$ & $15736(82.4)$ & $\begin{array}{l}\text { Interview on symptoms, exacerbations, diagnosis, use of medication } \\
\text { and health status. Pre-bronchodilator spirometry }\end{array}$ \\
\hline HUNT70+ & Everyone aged $\geq 70$ years & 9930 & $\begin{array}{l}\text { Tests of cognitive and physical functions, to be described in detail in a } \\
\text { separate publication }\end{array}$ \\
\hline \multirow[t]{4}{*}{ Blood samples } & All participants & 〜 52 200-54 600 & $\begin{array}{l}\text { Hemoglobin, blood cell counts, creatinine, total and HDL cholesterol, } \\
\text { triglycerides, HbA1c, CRP, troponin I, TSH (free thyroxine and TPO } \\
\text { antibodies in subgroups), coeliac serology, PEth } \\
\text { DNA extraction and genotyping }\end{array}$ \\
\hline & Buffy for DNA extraction & 52772 & Stored at $-80^{\circ} \mathrm{C}$ for future analyses \\
\hline & Plasma & 52830 & Stored at $-80^{\circ} \mathrm{C}$ for future analyses \\
\hline & Serum & 54523 & Stored at $-80^{\circ} \mathrm{C}$ for future analyses \\
\hline \multirow[t]{2}{*}{ Urine samples } & Previous participants of HUNT2 and 3 & 26961 & Analysed: creatinine, albumin \\
\hline & Microalbuminuria Study and $\sim 40 \%$ & & Stored at $-80^{\circ} \mathrm{C}$ for future analyses \\
\hline
\end{tabular}

random samples in large and some

small municipalities, limited by logistic factors 


\begin{tabular}{|c|c|c|c|}
\hline Saliva samples & $\begin{array}{l}30 \% \text { random sample in the same } \\
\text { municipalities as for urine samples }\end{array}$ & 17111 & Stored at $-80^{\circ} \mathrm{C}$ for future analyses \\
\hline Feces samples & $\begin{array}{l}\text { Age } 19-80 \text { years, invited after or at the } \\
\text { time of participation }\end{array}$ & $13270(25.7)$ & Ongoing microbiome analyses \\
\hline \multicolumn{4}{|c|}{ Ancillary studies, performed after the main clinical examination } \\
\hline Fitness & $\begin{array}{l}\text { Self-reported or hospital- } \\
\text { diagnosed atrial fibrillation at HUNT3 } \\
\text { or } 4 \text {, and participants in the HUNT3 or } \\
\text { Young-HUNT3 Fitness Study or HUNT3 } \\
\text { Echo Study }\end{array}$ & $2448(42.5)$ & $\begin{array}{l}\text { Cardiopulmonary Exercise Test (CPET) } \\
\text { Interview }\end{array}$ \\
\hline Heart & Same as for Fitness & $2448(42.5)$ & $\begin{array}{l}\text { Echocardiography } \\
\text { Pulse wave velocity by Doppler }(n=852)\end{array}$ \\
\hline $\begin{array}{l}\text { Cognitive } \\
\text { function }\end{array}$ & All participants & $5236(9.3)$ & Web-based cognitive tests \\
\hline Osteoporosis & $\begin{array}{l}\text { Participants in HUNT2, } 3 \text { or } \\
4 \text { Osteoporosis or Lung Study }\end{array}$ & $7540(64.2)$ & Dual-energy X-ray absorptiometry (DXA) of hip and lumbar spines \\
\hline Psychiatry & Random sample aged $20-65$ years & $2092(21.8)$ & $\begin{array}{l}\text { 1-2-hour structured interview on mental symptoms, treatment and } \\
\text { use of drugs }\end{array}$ \\
\hline MRI brain & $\begin{array}{l}\text { Participants in HUNT3 MRI-study } \\
\text { and } 15 \% \text { random sample of HUNT4 } \\
\text { participants aged } 20-66 \text { years resident } \\
\text { in Levanger or Verdal municipalities }\end{array}$ & $\begin{array}{l}1000 \text { by } \\
\text { September } 2021\end{array}$ & $\begin{array}{l}\text { MRI of brain, planned to include } 1500 \text { persons. Data collection } \\
\text { continues until July } 2022\end{array}$ \\
\hline Coeliac disease & $\begin{array}{l}\text { All participants with positive coeliac } \\
\text { serology }\end{array}$ & $\begin{array}{l}650(93) \\
\text { (June 2021) }\end{array}$ & $\begin{array}{l}\text { Questionnaire, endoscopy with biopsies, sampling of blood, feces } \\
\text { and saliva, ongoing data collection. Ongoing, planned to include } 800 \\
\text { people. Data collection phase I continues until December } 2021\end{array}$ \\
\hline \multicolumn{4}{|c|}{ HUNT4-S (Sør-Trøndelag region) } \\
\hline $\begin{array}{l}\text { Q1 } \\
\text { Web or printed }\end{array}$ & $\begin{array}{l}\text { All residents of } S \varnothing r-T r \varnothing \text { ndelag aged } \\
\geq 18 \text { years, unless they participated in } \\
\text { the HUNT4-S70+ study or were }\end{array}$ & $105966(42.8)$ & Similar to Q1 in HUNT4-N \\
\hline
\end{tabular}


included in the HUNT4-N emigration

\section{study}

HUNT4-S70+ $\quad$ Residents $\geq 70$ years in districts of

1745 (33.8) Similar to HUNT70+

Trondheim municipality

Abbreviations: BW, bitewing; CAM, complementary and alternative medicine; CRP, C-reactive protein; FFQ, Food Frequency Questionnaire; HDL, high-density lipoprotein $\mathrm{MRI}$, magnetic resonance imaging; OPG, orthopantomogram; PEth, phosphatidylethanol; Q, questionnaire; TPO, thyroid peroxidase, TSH, thyroid stimulating hormone

${ }^{a}$ No overlap with random samples for the lung study, the osteoporosis study, or the arthritis study. Overlap with the Oral Health Study.

${ }^{\mathrm{b}}$ Fewer than height/weight as not all participants could be measured barefoot

${ }^{\mathrm{c}}$ No overlap with random sample for the lung study, the osteoporosis study, or the arthritis study

d Examinations only in larger municipalities (Stjørdal, Levanger, Verdal, Steinkjer, Namsos and Nærøy), but questionnaires in all municipalities 
medRxiv preprint doi: https://doi.org/10.1101/2021.10.12.21264858; this version posted October 29, 2021. The copyright holder for this preprint (which was not certified by peer review) is the author/funder, who has granted medRxiv a license to display the preprint in All rights reserved. No reuse allowed without permission.

Figure legends

Figure 1. Flowchart of participation across the HUNT1-HUNT4 surveys and details on recruitment to HUNT4. The few individuals who have withdrawn their consent to participate in the HUNT Study have been excluded, and the numbers therefore deviate slightly from those reported in previous HUNT cohort profiles. NT, Nord-Trøndelag region; ST, Sør-Trøndelag region.

Figure 2. Prevalence of cardiovascular risk factors in HUNT1 (1984-86), HUNT2 (1995-97), HUNT3 (2006-08) and HUNT4-N (2017-19), by sex, age-standardized (direct method using 10-year age categories) to the Norwegian population on January 1, 2020. Point estimates with $95 \%$ confidence intervals are provided in Supplementary Table S4. 
Figure 1.

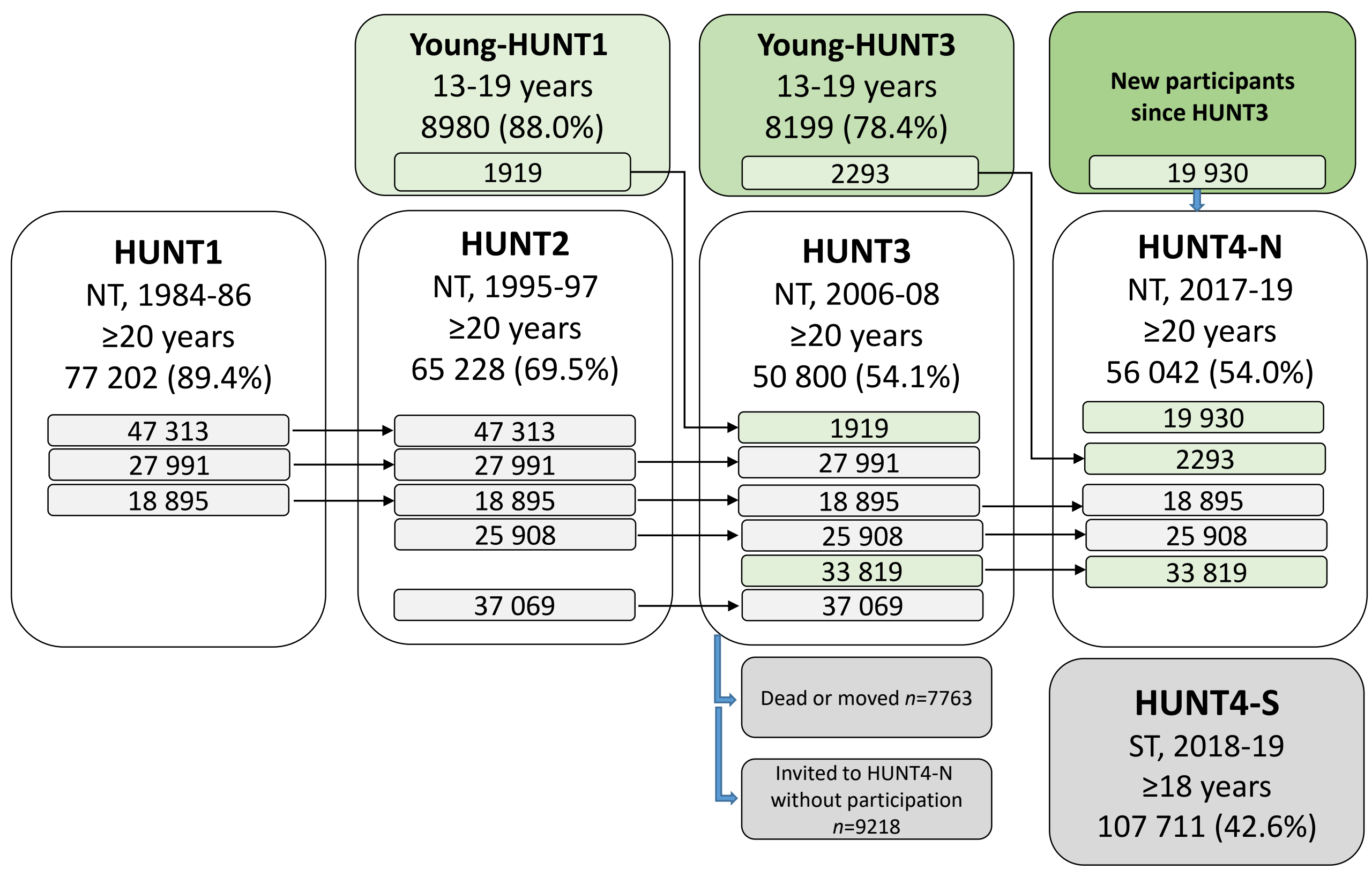




\section{Figure 2.}

\section{4-86 1995-97 2006-08 2017-19}

Total serum cholesterol $\geq 5.0 \mathrm{mmol} / \mathrm{l}$, men Total serum cholesterol $\geq 5.0 \mathrm{mmol} / \mathrm{l}$, women Blood pressure $\geq 140 / 90 \mathrm{mmHg}$, men Blood pressure $\geq 140 / 90 \mathrm{mmHg}$, women Current daily smoking, men Current daily smoking, women Body mass index $\geq 30 \mathrm{~kg} / \mathrm{m} 2$, men Body mass index $\geq 30 \mathrm{~kg} / \mathrm{m} 2$, women Self-reported diabetes, men Self-reported diabetes, women

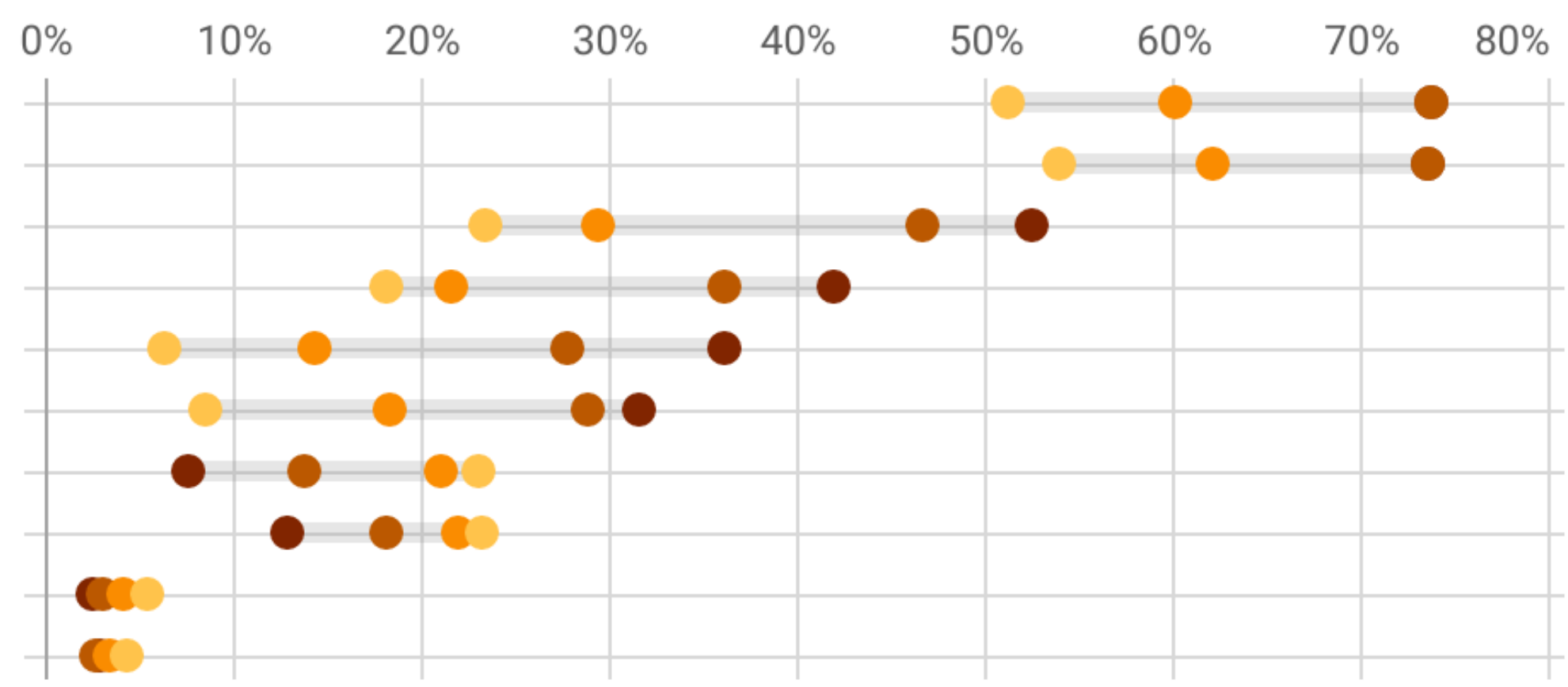

